\title{
Effect of Firm Size on Corporate Borrowing of Oil and Gas Firms in Nigeria
}

\section{Inyiama Oliver Ikechukwu, Ubesie Cyril Madubuko}

Department of Accountancy, Enugu State University of Science and Technology, Enugu, Nigeria

Email address:

ubesiemadubuko@yahoo.com (U. C. Madubuko)

\section{To cite this article:}

Inyiama Oliver Ikechukwu, Ubesie Cyril Madubuko. Effect of Firm Size on Corporate Borrowing of Oil and Gas Firms in Nigeria. International Journal of Economics, Finance and Management Sciences. Vol. 4, No. 5, 2016, pp. 303-308.

doi: $10.11648 /$ j.ijefm.20160405.21

Received: August 17, 2016; Accepted: August 29, 2016; Published: October 18, 2016

\begin{abstract}
The purpose of the research was to investigate to what extent the size of a firm in Nigeria oil and gas industry affects the magnitude of external borrowings. The study went further to examine the relationship between firm size and financial leverage in the same industry; as well as the causal relationship among the variables under study. Simple regression model was formulated to guide the analysis. The analysis of the time series data reveals that financial leverage is significantly but negatively affected by firm size in the industry. This implies that as firms increase in total assets, the firms tend to play down on sourcing for fund through external borrowing. The outcome is in line with some previous studies and in accordance with the theoretical framework of the study. There is no causality running from either Firm Size to Financial Leverage or otherwise, at 2 years lagged period; which implies that Financial Leverage does not granger cause Firm Size and vice versa. A negative relationship was revealed between firm size and financial leverage; though very insignificant; which implies that firm size and financial leverage change/increase in opposite direction in oil and gas industry. Therefore, firms at growth age, with a growing asset base, will need external borrowing more than a firm at mature or declining age with huge asset base and accumulated retained earnings.
\end{abstract}

Keywords: Leverage, Size, Oil, Gas, Regression, Correlation

\section{Introduction}

In financial affairs of companies, financial leverage is a very important factor in the business sectors, especially working in the developing countries [1].Effective financial leverage is very important due to its significant effect on profitability of company and thus the existence of company in the marke $t[12]$. The privileges and rights which a company enjoys within, around and outside it may be a factor of size; in terms of current and fixed asset base. The financial institutions should be more disposed to advance credits to companies with a sound asset base. This is because such firms would be able to provide marketable collateral securities for such borrowings. Many notable researchers such as [15] had found enough evidence to associate industrial and economic growth with the growth in asset base.[6] emphasizes that profit interacts with size. This implies that large firms are less susceptible to bankruptcy because they tend to be more diversified than smaller companies.

In this study, firm size is defined in line with [13] who defines firm size in terms of total assets held by an organization. Though, [6] opines that total assets and sale turnover are commonly used as a substitute for the size of the firm. The researcher believes that larger firms not only enjoy a higher turnover but also generate higher income. In the researchers view, the reason is that they have better access to capital markets and lower cost of borrowing; as large firms are more likely to manage their working capitals more efficiently than small firms. The study concludes that most large firms enjoy economies of scale and thus they are able to minimize their costs and improve on the profitability of the firm.[7]states that in the presence of non-trivial fixed costs of raising external funds large firms have cheaper access to outside financing per each dollar borrowed. Secondly, larger firms are more likely to diversify their financing sources; while alternatively, size may be a proxy for the probability of default, for it is sometimes contended that larger firms are 
more difficult to fail and liquidate, or, once the firm finds itself in distress, for recovery rate.

[2] emphasized that large firms tend to have more leverage perhaps because they are more transparent; have lower asset volatility; more diversified; naturally sell large enough debt issues so that the fixed costs of public borrowing are not prohibitive; have lower probability of default and less financial distress costs; while small firms incur higher costs of issuing debt or equity since they are subject to severe asymmetric information problems and default risk, more likely to be growing firms with volatile cash flows and hence have less access to external funds than do large firms. Despite all these, [15] still concludes that they do not really understand why size is correlated with leverage. This is a confirmation of the need for more elaborate studies on the link between firm size and corporate borrowing; especially in emerging economies of which Nigeria falls within. The study concentrates on the Nigeria Oil and Gas industry which is the mainstay of the nation's economy. The industry contributes the greatest portion to Gross Domestic Product of Nigeria and also to the distributable pool of fund into the federation account.

The data series collected from annual accounts and reports of the sampled oil and gas firms will be analyzed in order to examine the effect of firm size on corporate borrowing. The study will assess both the causality and relationship of the focal (dependent) variable with the explanatory (independent) variables. The remaining part of the paper is arranged into four sections as follows: Section 2 is for review of existing literature, Section 3 explains the methodology to be applied for data collection and analysis, Section 4 discusses the outcome of the data analysis, while section 5 concludes.

\section{Review of Related Literature}

The life cycle theory of dividends by [10] argues that a firm has a relatively well-defined life cycle, which is fundamental to the firm life cycle theory of dividends. Mueller added that as firms develop and age through its' life cycle, they tend to alter the dividend policy depending on the financial demands of a particular stage. This could be interpreted to imply that firms at their early stages of growth are likely to retain more earnings for expansion, thereby paying lesser dividend than older firms.More matured and older firms are likely to pay more dividends as growth opportunities would have dwindled; though with a huge asset size generated over the years.

The pecking order theory of capital structure is also among the most influentialtheories of corporate leverage and according to [11], due to adverse selection, firms prefer internal to external finance. The researcher stated that even when outside funds are necessary, firms still have preference to debt compared to equity because of lower information costs associated with debt issues. The ideas of [11] were further refined into a key testable prediction by [16]. The researcher reiterated that financing deficit should normally be matched dollar-for-dollar by a change in corporate debt.
Therefore, the researchers explained that if firms follow the pecking order, then in a regression of net debt issues on the financing deficit, a slope coefficient of one is observed.

[4] examines the nature and significance of firm size as a determinant of corporate financial leverage from an undeveloped market perspective. The researcher used a panel data fixed-effects regression model to ascertain if firm-age is positively and significantly related to financial leverage. The aim is to provide an important insight on the international debate on the effects of size on corporate decisions by estimating the relationship between financial leverage and firm size, while controlling also for the effects of other acclaimed determinants like asset tangibility, profitability and firm age. The scope is 71 firms quoted in the Nigerian stock markets over a 17-year period (1990-2006). The study reports that as much as 91.4 percent of the total finances of Nigerian-quoted firms were of short-term liabilities, with just 8.6 percent constituting long-term liabilities. Furthermore, that firm size is negatively and significantly related to financial leverage. The researcher however controlled for some other determinants and finds that the arising results tend to confirm an over-bearing influence of the pecking order theory in the financing patterns of Nigerian-quoted firms; by revealing that the relationship between profitability and financial leverage is highly significant and negative.

[18]drew on a comprehensive set of data of all registered firms in Thailand to examine whether firm size affects the relation between leverage and operating performance during the global financial crisis of 2007-2009. The study made use of a data set of 496,430 firm-year observations of a sample of 170,013 firms and find that the magnitude of the effect of leverage on operating performance is non-monotonic and conditional on firm size. The researchers' panel regression results indicate that leverage has a negative effect on performance across firm size sub-samples. The year-by-year cross-sectional regression results show that the effect of leverage on performance is positive for small firms and is negative for large firms. The findings of the study show that about $75 \%$ of Thai firms in our sample appear to have managed to get through the global financial crisis on the basis that they do not have to simultaneously deleverage and liquidate their assets.

The purpose of the study conducted by [9] was to establish the relationship between firm size and financial leverage of companies listed at the Nairobi Securities Exchange. Specifically the study sought to establish the effect of firm size, profitability and sales volume on financial leverage of companies listed Nairobi Securities Exchange. Based on the trade off and pecking order theory, the study builds a comprehensive framework to answer the research question on whether firm size affects financial leverage of firms listed at Nairobi Securities Nairobi. A census survey was carried out on all the 64 listed companies between 2010 and 2014 in Nairobi Securities Exchange. The financial leverage was measured using debt/equity. The variables were tested using regression analysis and Pearson's Product Moment Correlation analysis and the findings were that the 
relationship between firm size and financial leverage was statistically significant. There was a significant positive relationship between firm size and financial leverage. The study also confirmed that there is a negative significant relationship between profitability (ROA) and financial leverage, while a negative significant relationship exists between sales volume and financial leverage. The study not only contributes to understanding the link between firm size and financial leverage but at the same time confirms the findings of previous studies that have found a significant link between firm size and financial leverage.

Firm size has been empirically found by [7] to be strongly positively related to capital structure. This paper investigates whether a dynamic capital structure model can explain the cross-sectional size-leverage relationship. The driving force considered is the presence of fixed costs of external financing that lead to infrequent restructuring and create a wedge between small and large firms. The researchers found four firm size effects on leverage. Small firms choose higher leverage at the moment of refinancing to compensate for less frequent rebalancing, but longer waiting times between refinancings lead on average to lower levels of leverage. Within one refinancing cycle the relationship between leverage and firm size is negative. Finally, the researchers found that there is a mass of firms opting for no leverage. The analysis of dynamic economy demonstrates that in crosssection, therelationship between leverage and size is positive and thus fixed costs of financing contribute to the explanation of the stylized size-leverage relationship. However, the relationship changes the sign when the researchers control forthe presence of unlevered firms.

[3]found that small firms have lower leverage ratios, not because of internally generated funds or additional debt financing (as implied by the pecking order theory) but because of additional equity financing (consistent with our financial flexibility hypothesis). The researcher believed that the finding can be explained by neither of the pecking order theory and the tradeoff theory and that the pecking order may be reversed for small firms that prefer external equity to debt financing while the tradeoff theory may miss out some important aspects of capital structure decisions. The researcher argues that small firms maintain low leverage by issuing equity and building up cash holdings for financial flexibility and that debt covenant often carry restrictions on financing and investment decisions that are especially cumbersome for small, growing firms. Equity financing allows small firms to raise cash without impeding financial flexibility. Consistent with this argument, the researcher finds small firms build up cash holdings in order to preserve financial flexibility through external equity.

[2] investigate the impact of firm size, asset tangibility and retained earnings on the financial leverage. In this regard, auto sector was taken as case consisting of sub-sectors namely motor vehicles, trailers and auto parts. Data pertaining to 22 firms was collected from the financial statement analysis document issued by the State Bank of Pakistan (SBP). The results indicated that firm size and asset tangibility significantly affect the financial leverage. Moreover, negative relationship was noted between the respective variables. It was found that retained earnings have no significant impact on financial leverage.

The main purpose of the study carried out by [12] is to investigate the effect of Profitability, andfirm's Size as independent variables on leverage as proxy of Debt to Total Assets ratio(leverage) as dependent variable. A sample of 52 Jordanian Industrial listed companies on Amman Stock Exchange (ASE) for the year ended Dec. 31, 2013 was selected. The results of the research show that there is a significant effect of profitability in for of ROA, and size on leverage of industrial companies, on the contrary, ROE has not. Therefore, industrial companies may enhance the profitability of their firms by maximizing the profit, and increasing financial assets compared with total assets.

[5]investigates the factors that influence financial leverage of Canadian firms. A sample of 166 Canadian firms listed on the Toronto Stock Exchange for a period of 3 years (from 2008-2010) was selected. This study applied co-relational and non-experimental research design andthe results show that financial leverage of Canadian firms is influenced by the collateralized assets, profitability, effective tax rate, firm size, growth opportunities, number of subsidiaries, and industry dummy. This study contributes to the literature on the factors that influence financial leverage of the firm and may be useful for financial managers, investors, and financial management consultants.

The main purpose of the study carried out by [1] is to investigate the impact of Financial leverage, Company's Growth, non-current / total assets ratio, and firm's Size as independent variables on profitability in proxy of Return On Assets ratio (ROA) as dependent variable. A sample of 25 Jordanian Industrial companies listed on Amman Stock Exchange(ASE) for a period of 10 years (from 1995-2005) was selected. The results of the research show that there is a significant effect of the Financial Leverage and Growth on profitability of industrial companies. Therefore, industrial companies may enhance the profitability of their firms by minimizing the debt, and increasing financial assets compared with total assets.

One of the criteria taken into consideration by investors when making decisions about participation in an investment opportunity is the liquidity of asset. Liquidity refers to the quick and ease of converting assets into cash. Liquidity of assets has two aspects: ease of exchange versus reduction of the value. An asset with high liquidity is the one that can be sold quickly without significant reduction in its value. An investor tries to consider liquidity risk of an asset and finally decides to buy it after comparing its risk with the risk of other available investment opportunities. Regarding this, [17] found that some firms may use leverage to increase their debt ratios. This investigation aimed to determine the relationship between financial leverage and liquidity rank of industrial and manufacturing companies listed on Tehran Stock Exchange. Moreover, in order to get a deepened investigation, the firm size was also studied. To this aim, a population of 
163 companies whose information was available for a fiveyear period (2009-2013) was selected. Regression analysis was used to test the hypothesis. The results indicated that firms with higher financial leverage enjoyed less liquidity. Furthermore, smaller companies had less liquidity comparing with medium-sized and large companies.

\section{Methodology}

\subsection{Data}

Time series data were obtained from Annual Reports and Accounts of the selected Oil and Gas firms in Nigeria; which includes, Mobil Oil Plc, Total Oil Plc, ConoilPlc and Oando Plc. The four companies were chosen for this study considering their position as market leaders in terms of volume of crude oil production, number of oil Wells, total assets and quantity of crude oil sales. Total assets' time series data were logged to reduce data size effects on the analysis.

Table 1. Description of Variables.

\begin{tabular}{|c|c|c|c|}
\hline $\mathbf{S} / \mathbf{N}$ & Title & Acronym & Mathematical Representation \\
\hline 1 & Firm Size & FirmSz & Fixed Assets + Current Assets \\
\hline 2 & $\begin{array}{l}\text { Financial } \\
\text { Leverage }\end{array}$ & FinLev & $\begin{array}{l}\text { Total Debt } \div \text { No. of Outstanding } \\
\text { Shares }\end{array}$ \\
\hline
\end{tabular}

Source: Author's Arrangement.

\subsection{Procedure for Data Analysis}

a. A graphical representation of the model variablesto show the movement in the value of the

b. variables (firm size and financial leverage) during the period of the study $(2000-2014)$.

c. Descriptive statistics to indicate the characteristics of the values of the model variables.

d. The coefficient of regression analysis at industry level to expose the natureand magnitude of the effect of firm size on financial leverage.

e. Coefficient of correlation to establish the strength and nature of the relationship between firmsize and financial leverage.

f. Granger Causality Test to examine if firm size causes financial leverage and vice versa.

g. Johansen Cointegration test to confirm the sustainability of the short run interactions of thevariables inthe long run.

\subsection{Model Specification}

The simple regression (prediction) model is statistically written as,

$$
\text { FinLevt }=\beta o+\beta 1 \text { FirmSzt }+\varepsilon t
$$

Where,

FinLev $=$ Financial Leverage

FirmSz $=$ Firm Size (Total Assets)

$\beta_{0}=$ coefficient (constant) to be estimated

$\beta 1=$ parameter of the independent variable (Firm Size) to be estimated

$\mathrm{t}=$ current period

$\varepsilon=$ stochastic disturbance (error) term

Granger-Causality test is conducted in the context of linear regression models and specified in bivariate linear autoregressive model of two variables $X_{1}$ and $X_{2}$ based on lagged values as applied by Pasquale (2006):

$$
\begin{gathered}
P p \\
X_{1}(t)=\sum A_{11, j} X_{1}(t-j)+\sum A_{12, j} X_{2}(t-j)+E_{1}(t) \\
j=1 j=1 \\
P p \\
X_{2}(t)=\sum A_{21, j} X_{1}(t-j)+\sum A_{22, j} X_{2}(t-j)+E_{2}(t) \\
j=1 j=1
\end{gathered}
$$

Where;

$p$ is the maximum number of lagged observations included in the equation, the matrix $A$ contains the coefficients of the equation (i.e., the contributions of each lagged observation to the predicted values of $X_{1}(t)$ and $X_{2}(t)$,

$\mathrm{X}_{1}$ is the FinLev which is constant while

$\mathrm{X}_{2}$ is the FirmSz, and

$E 1$ and $E 2$ are residuals (prediction errors) for each time series data.

\section{Discussion of Findings}

FIRMSZ

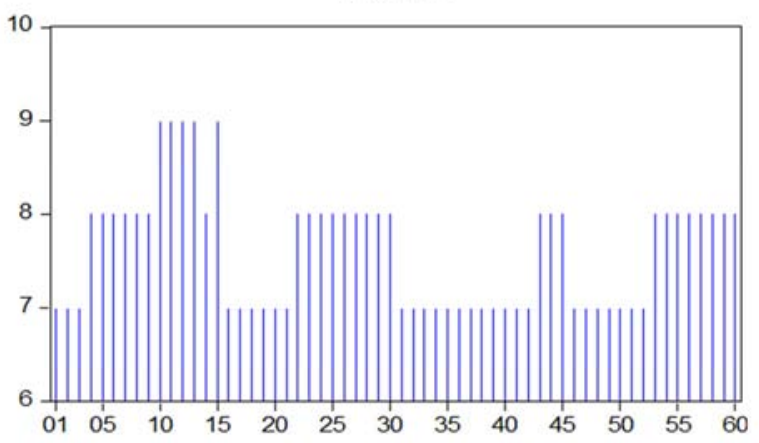

FINLEV

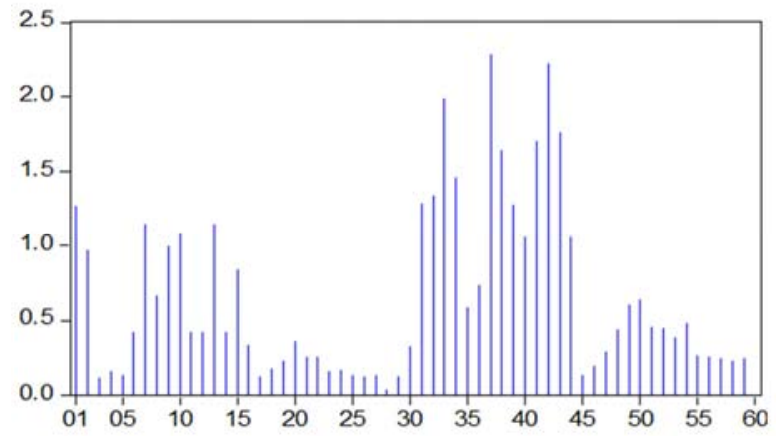

Figure 1. Spike Graph of Focal and Explanatory Variables.

Source: EView 8.0 Statistical Software Computation 
The graphical representations for firm size and financial leverage clearly indicate that as firm size is rising, financial leverage is decreasing. The whole selected firms depict the same trend of movement. This scenario is further confirmed by the outcome of the regression and correlation analysis; which depicts that financial leverage and firm size share negative relationship as seen below.

Table 2. Descriptive Statistics of the Variables.

\begin{tabular}{lll}
\hline STATISTICS & FIRMSIZE & FINANCIAL LEVERAGE \\
\hline Mean & 7.610169 & 0.661525 \\
Median & 8.000000 & 0.420000 \\
Maximum & 9.000000 & 2.280000 \\
Minimum & 7.000000 & 0.040000 \\
Std. Dev. & 0.643722 & 0.581994 \\
Skewness & 0.560821 & 1.150772 \\
Kurtosis & 2.363311 & 3.383448 \\
Jarque-Bera & 4.089327 & 13.38349 \\
Probability & 0.129424 & 0.001241 \\
Sum & 449.0000 & 39.03000 \\
Sum Sq. Dev. & 24.03390 & 19.64556 \\
Observations & 59 & 59 \\
\hline
\end{tabular}

Source: Author's EView 8.0 Output.

Table 2 describes the characteristics of variables of the study. The coefficient of skewnessfor $\operatorname{FirmSz}(0.560821)$ is less than 1 and this depicts a normal frequency distribution for firm size data series whileFinLev (1.150772)have values more than (1) signifying anabnormal frequency distribution for financial leverage data series. Kurtosis coefficient is 2.363311 and3.383448 for FirmSz and FinLev. This further confirms the scenario as explained with skewness statistics above.Jarque-Bera statistic shows that FirmSz has insignificant p-value of 0.129424 while FinLev has a significant p-value of 0.001241 . Both Kurtosis and JarqueBera statistic confirm that the time series data were normally distributed for FirmSz and otherwise for financial leverage.

Table 3. Regression Analysis.

\begin{tabular}{|c|c|c|c|c|}
\hline \multicolumn{5}{|c|}{ Dependent Variable: FINANCIAL LEVERAGE } \\
\hline \multicolumn{5}{|c|}{ Method: Least Squares } \\
\hline \multicolumn{5}{|c|}{ Date: 07/27/16Time: 01:49 } \\
\hline \multicolumn{5}{|c|}{ Sample (adjusted): 00010059} \\
\hline \multicolumn{5}{|c|}{ Included observations: 59 after adjustments } \\
\hline Variable & Coefficient & Std. Error & t-Statistic & Prob. \\
\hline FIRMSIZE & -0.225719 & 0.115960 & -1.946530 & 0.0498 \\
\hline $\mathrm{C}$ & 2.379288 & 0.885572 & 2.686723 & 0.0094 \\
\hline R-squared & 0.062330 & \multicolumn{2}{|c|}{ Mean dependent var } & 0.661525 \\
\hline Adjusted R-squared & 0.045880 & \multicolumn{2}{|c|}{ S.D. dependent var } & 0.581994 \\
\hline S.E. of regression & 0.568486 & \multicolumn{2}{|c|}{ Akaike info criterion } & 1.741631 \\
\hline Sum squared resid & 18.42105 & \multicolumn{2}{|c|}{ Schwarz criterion } & 1.812056 \\
\hline Log likelihood & -49.37810 & \multicolumn{2}{|c|}{ Hannan-Quinn criter. } & 1.769122 \\
\hline F-statistic & 3.788978 & \multicolumn{2}{|c|}{ Durbin-Watson stat } & 0.684033 \\
\hline Prob(F-statistic) & 0.056526 & & & \\
\hline
\end{tabular}

Source: Author's EView 8.0 Output.

Table 3 reveals that Firm Size has a significant negative effect on Financial Leverage at 5\% level of significance. This implies that as firm increases in size, especially in the capital intensive oil and gas industry, the firms tend to reduce the rate of borrowing. In line with Pecking Order Theory, companies tend to finance their expansions and growth through retained earnings because it is a near cost free source of fund to corporations. So at maturity, the companies would have accumulated enough reserves through which their investments could be financed. Secondly, in line with Life Cycle Theory, as companies advance in age, it picks up all investments opportunities available to it, but at maturity, it would have harnessed almost all opportunities. At this stage and beyond, it pays more dividends to the shareholders, retains lesser earnings and may no longer have need for external loans. This is in line with expectations of the researcher as borrowings are usually extremely necessary when accumulated savings dries up, or at most, reduces.

Table 4. Correlation Analysis Result.

\begin{tabular}{lll}
\hline & FINLEV & FIRMSZ \\
\hline FINLEV & 1.000000 & -0.249660 \\
FIRMSZ & -0.249660 & 1.000000 \\
\hline
\end{tabular}

Source: Author's EView 8.0 Output.

Table 4indicates a negative and insignificantrelationship between firm size and financial leverage in Nigeria Oil and Gas industry. The relationship between financial leverage and firm size is very weak and stands at about $25 \%$.

Table 5. Pairwise Granger Causality Tests.

\begin{tabular}{llll}
\hline Date: 07/27/16Time: 01:54 & & & \\
\hline Sample: 0001 0060 & & & \\
\hline Lags: 1 & Obs & F-Statistic & Prob. \\
\hline Null Hypothesis: & 58 & 1.79476 & 0.1859 \\
\hline FIRMSZ does not Granger CauseFINLEV & & 0.24591 & 0.6219 \\
\hline
\end{tabular}

Source: Author's EView 8.0 Output.

Table 6. Johansen Cointegration Test.

\begin{tabular}{|c|c|c|c|c|}
\hline \multicolumn{5}{|c|}{ Date: 07/27/16Time: 01:58 } \\
\hline \multicolumn{5}{|c|}{ Sample (adjusted): 00030059} \\
\hline \multicolumn{5}{|c|}{ Included observations: 57 after adjustments } \\
\hline \multicolumn{5}{|c|}{ Trend assumption: Linear deterministic trend } \\
\hline \multicolumn{5}{|c|}{ Series: FINLEV FIRMSZ } \\
\hline \multicolumn{5}{|c|}{ Lags interval (in first differences): 1 to 1} \\
\hline \multicolumn{5}{|c|}{ Unrestricted Cointegration Rank Test (Trace) } \\
\hline Hypothesized & & Trace & 0.05 & \\
\hline No. of CE(s) & Eigenvalue & Statistic & Critical Value & Prob.** \\
\hline None $*$ & 0.179859 & 17.99919 & 15.49471 & 0.0205 \\
\hline At most $1 *$ & 0.110856 & 6.697301 & 3.841466 & 0.0097 \\
\hline $\begin{array}{l}\text { Trace test indi } \\
* \text { denotes rejec } \\
\text { **MacKinnon }\end{array}$ & $\begin{array}{l}\text { ates } 2 \text { cointeg } \\
\text { tion of the hy } \\
\text { Haug-Michel }\end{array}$ & $\begin{array}{l}\text { ingeqn(s) at } t \\
\text { hesis at the } 0 \\
\text { 1999) p-valu }\end{array}$ & $\begin{array}{l}0.05 \text { level } \\
\text { level }\end{array}$ & \\
\hline \multicolumn{5}{|c|}{ Unrestricted Cointegration Rank Test (Maximum Eigenvalue) } \\
\hline Hypothesized & & Max-Eigen & 0.05 & \\
\hline No. of CE(s) & Eigenvalue & Statistic & Critical Value & Prob.** \\
\hline None & 0.179859 & 11.30188 & 14.26460 & 0.1397 \\
\hline At most $1 *$ & 0.110856 & 6.697301 & 3.841466 & 0.0097 \\
\hline \multicolumn{5}{|c|}{$\begin{array}{l}\text { Max-eigenvalue test indicates no cointegration at the } 0.05 \text { level } \\
* \text { denotes rejection of the hypothesis at the } 0.05 \text { level } \\
\text { **MacKinnon-Haug-Michelis (1999) p-values }\end{array}$} \\
\hline
\end{tabular}

Source: Author's EView 8.0 Output. 
On causalities as shown in Table 5, there is no causality running from either Firm Size to Financial Leverage or from Financial Leverage to Firm Size, at 1 year lagged period. The implication is that Financial Leverage does not granger cause Firm Size and vice versa.

\section{Summary and Conclusion}

The purpose of the study is to examine the effect of firm size on financial leverage in Nigeria oil and gas industry. The study also assesses the nature of the relationship, the causalities and its' level of significance between the variables. Ordinary least squares method in the form of simple regression was applied in the analysis.

The outcome of the analysis reveals that financial leverage is significantly but negatively affected by firm size in the sector. This implies that as firm increases in total assets, the firms tend to play down on sourcing for fund through external borrowing. This is because as the firm go through its' life cycle, from early stage of growth to maturity stage, it tends to accumulate funds by retaining a greater percentage of its' earnings. The fund is accumulated for investment purposes and when this accumulation becomes significant, it is ploughed back into business to finance growth strategies of the firm. This outcome is in line with some previous studies carried out on the subject. It is also in accordance with the main theoretical framework of the study; Pecking Order Theory and Life Cycle Theory.

There is no causality running from either Firm Size to Financial Leverage or otherwise, at 2 years lagged period. The implication is that Financial Leverage does not granger cause Firm Size and vice versa. A negative relationship was revealed between firm size and financial leverage; though very insignificant. This implies that firm size and financial leverage change/increase in opposite direction in oil and gas industry.

Though [8]believes that as firms grow older, their performance deteriorates; among other things, return on assets goes down, costs go up, and market size shrinks, their asset size, in terms of total assets, tends to grow with age. The view painted by [8]could partly be correct especially in terms of earnings. Life Cycle theory lends support to the scenario because the theory postulates that at maturity, a firm must have taken up most of the investment opportunities available to it and will be more interested in consolidation than diversification. At this stage, the firms payout more dividend and retain less as working capital. The implication of all these is that a firm that has a strong asset and investment base may not have need for external borrowing, instead, the firm ploughs back its' accumulated savings from retained earnings. Hence, firms at growth age, with a growing asset base, will need external borrowing more than a firm at mature or declining age with huge accumulated retained earnings and fewer investment opportunities.

\section{References}

[1] Alghusin, S. A. (2015). Do Financial Leverage, Growth and Size Affect Profitability of Jordanian Industrial Firms Listed. International Journal Of Academic Research In Business And Social Sciences. 5(4), 385-398.

[2] Baloch, B., Ihsan, A. \& Kakakhel, J. (2013) Impact of Firm Size, Asset Tangibility and Retained Earnings on Financial Leverage: Evidence from Auto Sector, Pakistan. Abasyn Journal of Social Sciences. 8(1), 143-155.

[3] Byoun, S.(2007). Financial Flexibility, Leverage, and Firm Size, 1-27, http://www.baylor.edu/business/finance/doc.php/231009.pdf

[4] Ezeoha, A.E. (2008). Firm size and corporate financial-leverage choice in a developingeconomy: Evidence from Nigeria, The Journal of Risk Finance. 9(4), 351-364.

[5] Gill, A. and Mathur, N. (2011)Factors that Influence Financial Leverageof Canadian Firms, Journal of Applied Finance \& Banking, 1(2), 2011, 19-37.

[6] Kumar, P.C. (2004). Bid-ask spreads in U.S. equity markets, Quarterly Journal of Business and Economics, 43 3/4, 85-111.

[7] Kurshev, A. and Strebulaev, A.(2005) Firm Size and Capital Structure,http://www.haas.berkeley.edu/groups/finance/KuSt-Paper2005.

[8] Loderer, C.and Waelchli, U.(2009). Firm Age and Performance,http://www.bi.edu/InstitutterFiles/Finans/Firm_age_perfo rmance.pdf

[9] Marete, D. (2011) The Relationship Between Firm Size and Financial Leverage of Firms Listed at Nairobi Securities Exchange, 1-59. repository.uonbi.ac.ke

[10] Mueller, D, C. (1972). "A Life Cycle Theory of the Firm," Journal of Industrial Economics. (20)3,199-219.

[11] Myers, S. C. (1984). "The Capital Structure Puzzle". Journal of Finance. 39 (3), 575-592.

[12] Nawaiseh, S. R. (2015). Do Profitability and Size Affect Financial Leverage of Jordanian Industrial Listed Companies. European Journal of Business and Innovation Research. 3(5), 1-12.

[13] Pandey, M. (2004).Capital structure, profitability and market structure: evidence from Malaysia, Asia Pacific Journal of Economics and Business, 8 (2); 23-38.

[14] Pasquale, F. (2006). "Testing for Granger Causality between Stock Prices and Economic Growth”. MPRA Paper 2962, University Library of Munich, Germany, revised 2007.

[15] Rajan, G. R. \&Zingales, L. (1995). What do we know about capital structure? Some evidencefrom international data, The Journal of Finance. 50, 1421-60.

[16] Shyam-Sunder, L. and Myers, S (1999), Testing static tradeoff against pecking order models of capital structure, Journal of Financial Economics. 51, 219-244.

[17] Vakilifard, H. and Askarzadeh, G. (2015). Investigating the Effect of Financial Leverage and Firm Size on the Rank of Share Liquidity or Companies Listed on Tehran Stock Exchange, International Journal of Research In Social Sciences. 4(9), 72-78.

[18] Vithessonthi, C. and Tongurai, J. (2013).The Effect of Firm Size on the Leverage-Performance Relationship during the Financial Crisis of 2007-2009, 1 - 54. http://papers.ssrn.com/sol3/papers.cfm?abstract 